\title{
A Mutation in the Human Norepinephrine Transporter Gene (SLC6A2) Associated with Orthostatic Intolerance Disrupts Surface Expression of Mutant and Wild-Type Transporters
}

\author{
Maureen K. Hahn, ${ }^{1,2}$ David Robertson, ${ }^{2,3,4}$ and Randy D. Blakely ${ }^{1,2,4}$ \\ ${ }^{1}$ Department of Pharmacology, ${ }^{2}$ Center for Molecular Neuroscience, ${ }^{3}$ Department of Medicine, and ${ }^{4}$ Autonomic Dysfunction Center, Vanderbilt University \\ School of Medicine, Nashville, Tennessee 37232-8548
}

\begin{abstract}
The norepinephrine transporter (NET) mediates reuptake of norepinephrine released from neurons, and, as such, it is an important regulator of noradrenergic neurotransmission. Recently, our laboratory reported a polymorphism in the human NET (hNET) gene A457P in an individual with the autonomic disorder orthostatic intolerance (OI). The presence of the hNET-A457P allele tracked with elevated heart rates and plasma NE levels in family members. hNET-A457P lacks $>98 \%$ transport activity in several heterologous expression systems. In the present work, Western blot and biotinylation analyses performed in transiently transfected COS-7 cells revealed impairment in processing of hNET-A457P to the fully glycosylated form and a decrease in surface expression to $30 \%$ of hNET-wild type (hNET-wt). Because the hNET-A457P mutation is carried on a single allele in OI subjects, we examined the influence of cotransfection of hNET-wt and hNET-A457P and found that hNET-A457P exerts a dominant-negative effect on hNET-wt uptake activity. Experiments to determine oligomerization as a potential mechanism of the dominant-negative effect demonstrated that hNET-A457P coimmunoprecipitates with, and diminishes surface expression of, hNET-wt. These results reveal that hNET-A457P causes a conformational disruption that interferes with transporter biosynthetic progression and trafficking of both the mutant transporter and hNET-wt. These results elucidate a molecular mechanism for the disrupted NE homeostasis and cardiovascular function evident in OI patients with the hNETA457P mutation.
\end{abstract}

Key words: norepinephrine; transporter; SLC6A2; orthostatic intolerance; trafficking; antidepressant

\section{Introduction}

Noradrenergic neurotransmission in the brain mediates attention, learning and memory, and emotion and pain perception (Foote et al., 1983). Norepinephrine (NE) is also involved in autonomic control via its actions in the brainstem and as the primary neurotransmitter used at postganglionic sympathetic nerve terminals. NE released at central and peripheral synapses is inactivated through active transport into terminals by the presynaptically localized norepinephrine transporter (NET) (Iversen, 1961). Localized expression of NET to NE neurons is demonstrated by $\left[{ }^{3} \mathrm{H}\right]$ nisoxetine autoradiography (Tejani-Butt, 1992), gene expression (Lorang et al., 1994), NE uptake (Mitchell et al., 1994), and selective antibodies (Schroeter et al., 2000). NET recaptures as much as $90 \%$ of released NE, making it a critical mediator of NE inactivation and presynaptic catecholamine homeostasis (Schomig et al., 1989). Indeed, NET knock-out mice (Xu et al., 2000) exhibit both a diminished NE clearance rate and elevated extracellular NE concentrations, despite lowered tissue content. Finally, NET is a target for tricyclic antidepressants, NET-selective reuptake inhibitors and multiple psychostimu-

Received Sept., 6, 2002; revised March 13, 2003; accepted March 17, 2003.

This work was supported by National Institutes of Health Grants MH58921 (R.D.B.) and F32 MH12896 (M.K.H.) Correspondence should be addressed to Dr. Randy D. Blakely, Center for Molecular Neuroscience, 6133 Medical Research Building III, Suite 7140, Vanderbilt School of Medicine, Nashville, TN 37232-8548. E-mail: randy.blakely@vanderbilt.edu.

Copyright $\odot 2003$ Society for Neuroscience $\quad$ 0270-6474/03/234470-09\$15.00/0 lants, including amphetamine and cocaine (Ritz et al., 1990; Tatsumi et al., 1997; Sacchetti et al., 1999).

The human NET (hNET) is a member of the $\mathrm{Na}^{+} / \mathrm{Cl}^{-}$dependent GAT (GABA transporter)/NET transporter family (Nelson, 1998; Hahn and Blakely, 2002a) and is a single-copy gene (SLC6A2) located on chromosome 16 (Brüss et al., 1993). The hNET cDNA encodes a 617 amino acid protein sufficient to confer saturable, $\mathrm{Na}^{+}$-dependent NE uptake in transfected cells (Pacholczyk et al., 1991). hNET contains three canonical $\mathrm{N}$-glycosylation sites in the second extracellular loop, and immunohistochemical studies confirm a progression of hNET from light to more heavily glycosylated forms during synthesis of the mature protein (Pacholczyk et al., 1991; Melikian et al., 1994, 1996).

Although a role for compromised function of NE systems and NET in mood disorders has long been suspected (Schildkraut, 1965; Leonard, 1997), we recently demonstrated that NET dysfunction may also manifest as diseases of the cardiovascular system (Blakely, 2001; Hahn and Blakely, 2002b). Moreover, decreases in NE uptake sites and activity are observed in hypertension, diabetes, cardiomyopathy, and heart failure (Esler et al., 1981; Merlet et al., 1992; Bohm et al., 1995; Schnell et al., 1996; Backs et al., 2001), and insufficient NE clearance may contribute to disease progression (Bohm et al., 1998). NETs mediate a nonvesicular form of catecholamine release (Schomig et al., 1984). Efflux of cytoplasmic NE through NET during ischemia may contribute to fatal arrhythmias (Wilkerson and Sanders, 1978; Schomig et al., 1991). 
Our laboratory identified hNET-A457P, a mutant highly deficient in NE transport, in a subject with orthostatic intolerance (OI), a disorder characterized by elevated heart rate and accompanied by indices of a hyperadrenergic state (Shannon et al., 2000). The proband and family members carrying the heterozygous mutation also exhibited evidence of NET dysfunction (Jacob et al., 1999; Shannon et al., 2000). Although hNET-A457P has been shown to be deficient in transport, the molecular and cellular basis of its loss of its activity has not been defined. In the present study, we show that the defect of hNET-A457P lies in both disrupted biosynthetic processing and negligible function of residual surface transporters. Furthermore, coexpression of the mutant with hNET-wild type (hNET-wt) decreases the surface expression of hNET-wt and diminishes transport activity. Finally, we show that hNET-A457P coimmunoprecipitates with hNET-wt, providing evidence of oligomeric complexes that could underlie the presentation of severe hNET dysfunction in heterozygous subjects.

\section{Materials and Methods}

Plasmids constructs. The expression vector pcDNA3 (Invitrogen, Carlsbad, CA) containing the coding sequence for hNET, or hNET engineered with tags or substitutions, was used in all transfection experiments. Construction of the plasmids pcDNA3-hNET-wt bearing an introduced AflII site and pcDNA3-hNET-A457P has been described previously (Galli et al., 1995; Shannon et al., 2000; Bauman and Blakely, 2002). The plasmid pcDNA3-hNET-A457P contains a single nucleotide substitution of a C for a $G$ at position 237 (GenBank accession number 91127) to create the alanine to proline substitution found in OI subjects (Shannon et al., 2000). His-hNET-wt and HA-hNET-wt, containing a $[\mathrm{His}]_{6}$-Gly or a hemagluttinin (HA) epitope sequence in the $\mathrm{NH}_{2}$ terminus, respectively, were constructed using the QuikChange site-directed mutagenesis kit (Strategene, La Jolla, CA) according to the instructions of the manufacturer (Bauman and Blakely, 2002; Sung et al., 2003). His-hNET-A457P was created by subcloning an XhoI-AflII fragment containing the A457P mutation into His-hNET-wt. Sequences were confirmed using dideoxy terminators (Center for Molecular Neuroscience Neurogenomics Core, Vanderbilt University). HA-tag $\alpha 2 \mathrm{aAR}$ was kindly provided by Dr. Lee Limbird (Vanderbilt University, Nashville, TN).

Cell culture and transfection. All experiments were performed in transiently transfected COS-7 cells. COS-7 cells were maintained in DMEM (Invitrogen, Carlsbad, CA) supplemented with $10 \%$ fetal bovine serum (HyClone, Logan, UT), 2 mm L-glutamine (Invitrogen), and $0.1 \mathrm{U} / \mathrm{ml}$ penicillin- $0.11 \mathrm{gm} / \mathrm{ml}$ streptomycin (Invitrogen) in a humidified incubator at $37^{\circ} \mathrm{C}$ and $5 \% \mathrm{CO}_{2}$. One day before transfection, cells were plated in individual wells of 24-well plates at a density of $5 \times 10^{4}$ cells per well or, for membrane-binding experiments, in $150 \mathrm{~mm}$ dishes at a density of $5 \times 10^{6}$ cells per dish. Transfections were performed using Fugene 6 reagent as described by the manufacturer (Roche Molecular Biochemicals, Indianapolis, IN). All experimental manipulations were begun $\sim 24$ hr after transfection.

$\left[{ }^{125} I\right] R T I-55$ radioligand membrane binding. To estimate hNET membrane density, $3 \beta-\left[4-\left[{ }^{125} \mathrm{I}\right]\right.$ iodophenyl] tropan- $2 \beta$-carboxylic acid methyl ester ([ $\left.\left.{ }^{125} \mathrm{I}\right] \mathrm{RTI}-55\right)$ binding was performed similarly to that described previously (Melikian et al., 1994; Galli et al., 1995). [ ${ }^{125}$ I]RTI-55 binding to hNET-wt and hNET-A457P was performed using COS-7 membranes prepared by homogenization of cells in binding buffer (50 $\mathrm{mm}$ Tris- $\mathrm{HCl}, \mathrm{pH} 8.0$, and $100 \mathrm{~mm} \mathrm{NaCl}$ ) at $12,000 \mathrm{rpm}$ for $15 \mathrm{sec}$, followed by centrifugation at $20,000 \times g$ for $30 \mathrm{~min}$ at $4^{\circ} \mathrm{C}$. The membrane pellets were resuspended in binding buffer and incubated with a fixed concentration of $\left[{ }^{125} \mathrm{I}\right] \mathrm{RTI}-55$ (>2200 Ci/mmol; NEN, Boston, MA) and increasing concentrations of unlabeled RTI- 55 or other competitors (i.e., NE) for 45-90 min at room temperature. Nonspecific binding was defined by parallel incubations with $10 \mu \mathrm{M}$ desipramine (Sigma, St. Louis, MO). Assays were terminated by rapid filtration on a Brandel (Gaithersburg, MD) cell harvester through glass fiber filters preequilibrated in $0.3 \%$ polyethylenimine. Filters were counted in a gamma counter. Binding isotherms, Scatchard analyses, and competition curves were analyzed using Kaleidagraph curve-fitting software (Synergy Software, Reading, PA).

$\left[{ }^{125} I\right] R T I-55$ radioligand whole-cell binding. To ascertain the density of hNET binding sites on the cell surface, $\left[{ }^{125} \mathrm{I}\right] \mathrm{RTI}-55$ whole-cell binding was performed. Cells were washed three times with $1 \times \mathrm{PBS}$ before incubation with radiolabel and competitors. To assess nonspecific binding, cells were preincubated with or without $100 \mu \mathrm{M}$ dopamine for $10 \mathrm{~min}$ at $4^{\circ} \mathrm{C}$ in binding buffer. $\left[{ }^{125} \mathrm{I}\right] \mathrm{RTI}-55(10 \mathrm{nM})$ was added for $1 \mathrm{hr}$ at $4^{\circ} \mathrm{C}$. Cells were washed three times with binding buffer at $4^{\circ} \mathrm{C}$, solubilized in scintillation fluid (National Diagnostics, Atlanta, GA), and counted in a gamma counter.

$\left[{ }^{3} H\right] N E$ uptake assays. NE transport was assayed in Krebs'-Ringer'sHEPES (KRH) buffer as described previously (Melikian et al., 1994; Apparsundaram et al., 1998a). Briefly, cells were preincubated for $10 \mathrm{~min}$ at $37^{\circ} \mathrm{C}$, with or without $1 \mu \mathrm{M}$ desipramine to assess nonspecific accumulation, followed by the addition of $50 \mathrm{~nm}$ (single-point) or varying concentrations of (kinetic analysis) $\left[{ }^{3} \mathrm{H}\right] \mathrm{NE}(\sim 30 \mathrm{Ci} / \mathrm{mmol}$; Amersham Biosciences, Uppsala, Sweden). After $10 \mathrm{~min}$, cells were washed three times in KRH and incubated for $2 \mathrm{hr}$ in scintillation fluid (National Diagnostics), and accumulated $\left[{ }^{3} \mathrm{H}\right] \mathrm{NE}$ was determined by scintillation counting. Student's $t$ test (two-tailed) was used to compare means of transport and binding assays, and $p$ values $<0.05$ were considered significant.

Immunoblots. For preparation of detergent extracts of transfected cells, cells were solubilized in radioimmunoprecipitation assay (RIPA) buffer (10 mm Tris, pH 7.4, $150 \mathrm{~mm} \mathrm{NaCl}, 1$ mm EDTA, 0.1\% SDS, 1\% Triton $\mathrm{X}-100,1 \%$ sodium deoxycholate, $250 \mu \mathrm{M}$ PMSF, $1 \mu \mathrm{g} / \mathrm{ml}$ aprotinin, 1 $\mu \mathrm{g} / \mathrm{ml}$ leupeptin, and $1 \mu \mathrm{M}$ pepstatin) for $1 \mathrm{hr}$ at $4^{\circ} \mathrm{C}$ and centrifuged at $20,000 \times g$ for $30 \mathrm{~min}$, and supernatants were separated on $8 \%$ SDSPAGE gels. Proteins were transferred electrophoretically to polyvinylidene fluoride membrane (Millipore, Bedford, MA). Membranes were incubated with a monoclonal antibody directed against hNET at a dilution of 1:1000 (NET17-1; Mab Technologies, Stone Mountain, GA), followed by incubation with a goat anti-mouse HRP-conjugated secondary antibody at a dilution of 1:5000 (Jackson ImmunoResearch, West Grove, PA) or with an HRP-conjugated anti-HA antibody at a dilution of 1:500 (Roche Molecular Biochemicals), followed by antibody visualization using chemiluminescent reagents (PerkinElmer Life Sciences, Boston, MA). In experiments to determine the extent of complex $\mathrm{N}$-glycosylation of hNET-A457P, endoglycosidase H (EndoH) (New England Biolabs, Beverly, MA) treatments were performed. Lysates were denatured for $20 \mathrm{~min}$ at room temperature in $1 \times$ denaturing buffer ( $0.05 \%$ SDS and 1\% 2-mercaptoethanol), followed by incubation for 20

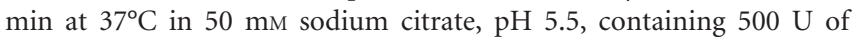
EndoH. Lysates were then subjected to SDS-PAGE and Western blotting as described above.

Cell surface biotinylation. To investigate the level of surface expression of hNET-A457P relative to hNET-wt and the impact of coexpression of different proteins on surface trafficking, biotinylation was performed on intact cells (Apparsundaram et al., 1998b). Cells were incubated with sulfosuccinimidyl-2-(biotinamido)ethyl-1,3-dithiopropionate(sulfo-NHS-SS-biotin) (1.0 mg/ml; Pierce, Rockford, IL) for $30 \mathrm{~min}$ at $4^{\circ} \mathrm{C}$, washed, quenched with $100 \mathrm{~mm}$ glycine, extracted in RIPA buffer, and incubated with Immunopure immobilized streptavidin beads (Pierce) for $45 \mathrm{~min}$ at room temperature. Beads were washed four times in RIPA buffer, and proteins bound to streptavidin beads were eluted in $1 \times$ Laemmli buffer containing 2-mercaptoethanol (Laemmli, 1970). Samples were then separated by $8 \%$ SDS-PAGE and immunoblotted as described for Western blot analyses.

Immunoprecipitation. To examine the presence of oligomeric interactions, tagged hNET constructs were used in coimmunoprecipitation experiments. Cell extracts were subjected to immunoprecipitation overnight at $4^{\circ} \mathrm{C}$ with $1.5 \mu \mathrm{g}$ of anti-His antibody (BD Biosciences Clontech, Palo Alto, CA), followed by $45 \mathrm{~min}$ of incubation with $10 \mu \mathrm{l}$ of a $50 \%$ slurry of protein-G Sepharose beads (Amersham Biosciences). Beads were washed four times with RIPA buffer, and the bound proteins were eluted with Laemmli buffer containing 2-mercaptoethanol and subjected to SDS-PAGE as described above. In experiments in which biotinylation 
preceded immunoprecipitation, proteins were collected on monomeric avidin beads (Pierce) and eluted by competition with $2 \mathrm{~mm}$ biotin.

Quantitation of immunoblots. Quantitation of band density was performed on scanned images using Quantity One software (Bio-Rad, Hercules, CA). The area of each band was selected using a drawing tool. Gel analyses were performed in replicates, and data are presented with representative blots and graphs of mean optical density from replicate experiments. Student's $t$ test (two-tailed) was used to compare means of band density determinations, and $p$ values $<0.05$ were considered significant.

\section{Results}

We reported previously that hNET-A457P lacked transport activity when transfected into multiple cell lines (Shannon et al., 2000). In the current study, we examined full saturation kinetics of $\left[{ }^{3} \mathrm{H}\right] \mathrm{NE}$ uptake in COS-7 cells and, consistent with our previous study, found that, whereas hNET-wt demonstrates saturable transport $\left(V_{\max }\right.$ of $1.4 \times 10^{-16} \mathrm{~mol} / \mathrm{min}$ per cell and $K_{\mathrm{m}}$ of 1.4 $\mu \mathrm{M})$, hNET-A457P exhibits transport levels of $\sim 1 \%$ of hNET-wt at concentrations from $10 \mathrm{nM}$ to $6 \mu \mathrm{M}$ (Fig. $1 A$ ). This transport deficit could be caused by impairments in protein expression levels or altered ability to bind or translocate substrate or aberrant trafficking to the cell surface. To address these possibilities, we first determined the density of hNET-A457P binding sites compared with hNET-wt using $\left[{ }^{125} \mathrm{I}\right] \mathrm{RTI}-55$ saturation binding to COS-7 cell membranes. hNET-wt exhibits saturable, highaffinity $\left[{ }^{125} \mathrm{I}\right]$ RTI-55 binding $\left(B_{\max }\right.$ of $1.1 \times 10^{-11} \mathrm{~mol} / \mathrm{mg}$ protein) sensitive to desipramine. In contrast, hNET-A457P demonstrated a $70 \%$ decrease in $B_{\max }$ for $\left[{ }^{125} \mathrm{I}\right] \mathrm{RTI}-55$ membrane binding (Fig. $1 B$ ). Scatchard transformation revealed a single population of high-affinity binding sites for both hNET-wt and hNET-A457P (Fig. $1 B$, inset). There was no change in apparent $K_{\mathrm{d}}$ of hNET-A457P compared with hNET-wt (7.6 and $15.3 \mathrm{nM}$, respectively). The decrease in $B_{\max }$ without an appreciable change in $K_{\mathrm{d}}$ suggests a decrease in the abundance of hNET A457P protein. Total membrane binding reflects the density of transporters in both intracellular and cell surface membranes. Thus, a loss of membrane binding sites less than the observed deficit in transport activity suggested to us an even greater loss of cell surface transporters. To assess this possibility, we performed whole-cell binding as an initial estimate of the density of cell surface transporters. We found whole-cell [ $\left.{ }^{125} \mathrm{I}\right] \mathrm{RTI}-55$ binding for hNET-A457P to be $\sim 30 \%$ of hNET-wt binding (data not shown). Together, these data suggest a diminished density of hNET protein engendered by the hNET-A457P mutation. In light of the evidence that NE transport deficits were much greater than changes in antagonist binding measures, in either isolated membranes or intact cells, we also assessed the integrity of the NE binding site through competition binding studies. Competition of [ $\left.{ }^{125} \mathrm{I}\right] \mathrm{RTI}-55$ with increasing concentrations of NE revealed an increase in the $K_{\mathrm{i}}$ of NE for hNET-A457P compared with hNET-wt (257.3 vs $46.8 \mu \mathrm{M})$ (Fig. 1C). Together, these radioligand-based measures suggest that transport deficits arise from both a decrease in the level of hNET-A457P protein compared with hNET-wt and diminished substrate recognition and permeation.

To examine directly the impact of hNET-A457P on protein expression, we performed Western blot analyses of transporter protein using NET-specific antibodies (Schroeter et al., 2000; Bauman and Blakely, 2002). Previous studies demonstrate several immunoreactive forms of hNET, representing different states of glycosylation achieved as hNET is processed to a mature form of $\sim 80 \mathrm{kDa}$ that is enriched in surface fractions in several cell types (Melikian et al., 1996). Consistent with these results, we observed
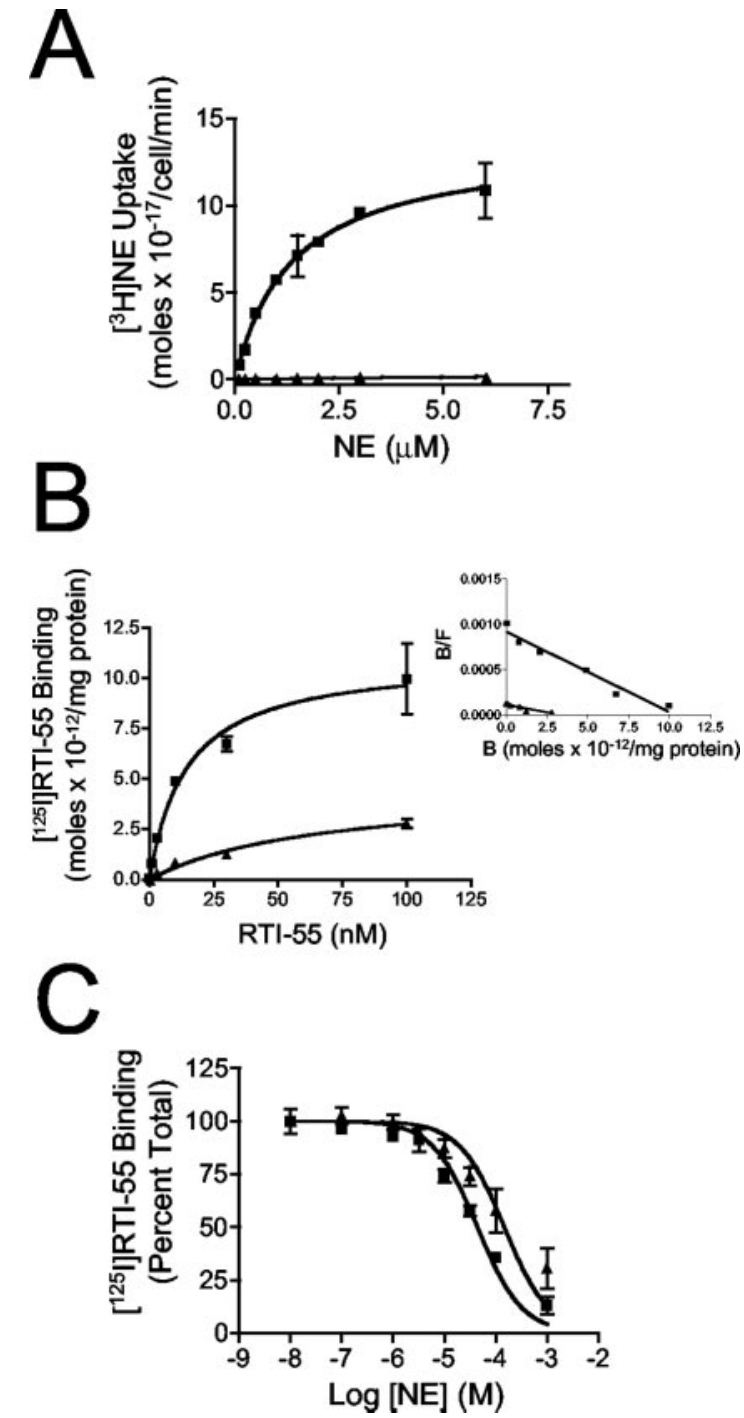

Figure 1. A, Saturation kinetics of [ $\left.{ }^{3} \mathrm{H}\right] \mathrm{NE}$ uptake of hNET-wt (squares) and hNET-A457P (triangles). COS-7 cells were transiently transfected with hNET-wt or hNET-A457P. Twenty-four hours later, cells were incubated for 10 min with $10 \mathrm{~nm}$ to $6 \mu \mathrm{m}\left[{ }^{3} \mathrm{H}\right] \mathrm{NE}$. Nonspecific binding was defined by $1 \mu \mathrm{m}$ desipramine. Data shown are from a representative experiment performed in triplicate at each $\left[{ }^{3} \mathrm{H}\right] \mathrm{NE}$ concentration. B, Saturation kinetics of $\left[{ }^{125} \mathrm{I}\right] \mathrm{RTI}-55$ binding to hNET in COS-7 cell membranes. COS-7 cells were transfected with hNET-wt (squares) or hNET-A457P (triangles). Twenty-four hours later, membranes were prepared, and [ $\left.{ }^{125}\right]$ RTI- 55 binding was performed by incubating membranes with $1 \mathrm{~nm}\left[{ }^{125} \mathrm{I}\right] \mathrm{RT}$ TI-55 and increasing concentrations of unlabeled RTI-55. Specific binding defined in the presence of $10 \mu \mathrm{m}$ desipramine is plotted as a nonlinear, least-squares fit to a single site binding isotherm. Data shown are from a representative experiment performed in duplicate at each RTI-55 concentration. Inset, Scatchard transformation of the raw data. C, NE competition of [ ${ }^{125}$ I]RTI-55 binding. COS-7 cells were transfected with hNET-wt (squares) or hNET-A457P (triangles). Twenty-four hours later, membranes were prepared, and NE (10 nм to $1 \mathrm{~mm}$ ) was used to compete $1 \mathrm{~nm}$ [ ${ }^{125}$ ]]RTI- 55 binding. Results are the mean \pm SEM of four experiments and are expressed as percentage of total [ ${ }^{125}$ I]RTI-55 binding with no competitor present.

two major forms of hNET-wt of $\sim 54$ and $80 \mathrm{kDa}$ in transiently transfected COS-7 cells (Fig. 2A). Extracts blotted from cells transfected with hNET-A457P demonstrated a large decrease in abundance of the $80 \mathrm{kDa}$ form, reaching levels of only $37.1 \pm$ $2.9 \%$ of hNET-wt, with little or no change in the abundance of the $54 \mathrm{kDa}$ form $(p<0.001 ; n=3)$ (Fig. $2 A, B)$. It is possible that the hNET-A457P mutation results in an inability of the $\mathrm{N}$-terminally directed antibody to recognize its epitope. This is unlikely because blots probed with an hNET antibody directed against the $\mathrm{C}$ 


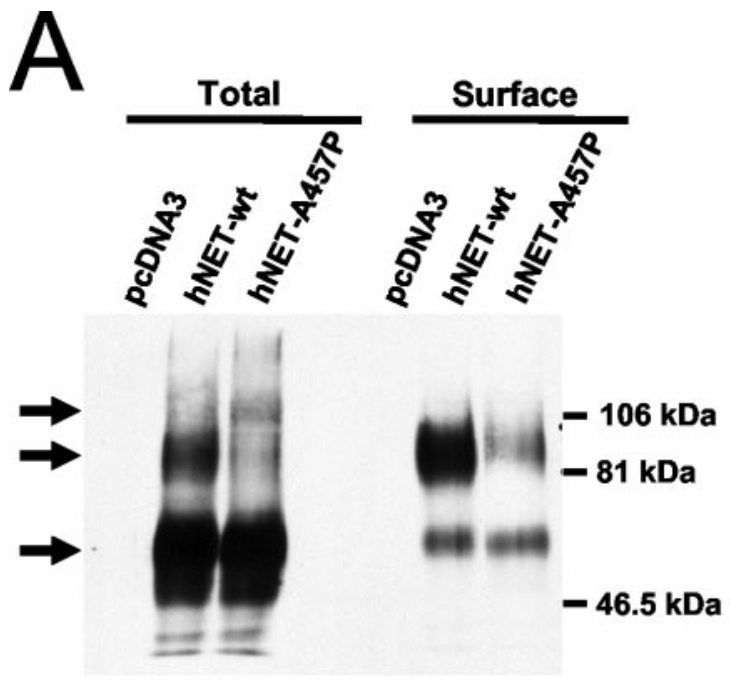

B
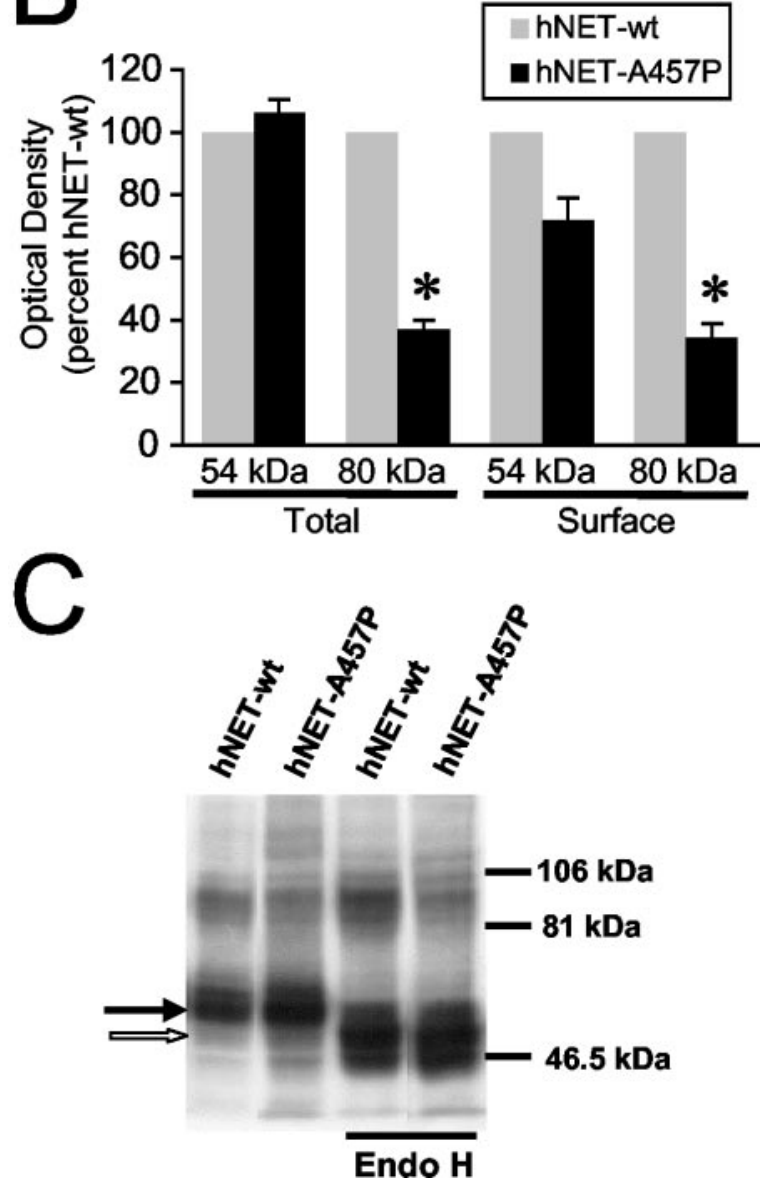

Figure 2. A, Western blot analysis of hNET-wt and hNET-A457P total cellular lysate and surface expression. COS-7 cells were transfected with pcDNA3, hNET-wt, or hNET-A457P. Twenty-four hours later, cells were incubated in sulfo-NHS-SS- biotin, followed by extraction in RIPA buffer containing protease inhibitors. Aliquots containing equal amounts of protein were taken from each sample for total hNET blots, and, from the remaining sample, aliquots of equal amounts of protein were extracted with strepatavidin beads as described in Materials and Methods. Blots were probed with a monoclonal antibody to hNET, followed by a goat antimouse HRP-conjugated secondary antibody and chemiluminescent detection. Arrows indicate the different molecular weight forms of hNET as described in Results. B, Quantitation from three separate experiments of the effects of hNET-A457P on total cellular lysate and surface protein expression in transiently transfected COS-7 cells performed as described in A. Results are expressed as percentage \pm SEM of hNET-wt band density for each protein species from three terminus (43411) yielded the same reduction of the $80 \mathrm{kDa}$ species (data not shown). Additionally, visible on the blots was a larger band predominant in hNET-A457P lysates compared with hNET-wt, which may represent an aggregate of misfolded proteins (Fig. $2 A$, top arrow).

The loss of the $80 \mathrm{kDa}$ form and evidence for diminished whole-cell binding suggested that decreased surface expression played a role in the lack of transport associated with hNETA457P. To explore this issue, cell surface labeling was performed using a cell-impermeant biotinylating reagent, followed by immunoblotting of extracts captured on streptavidin beads. Consistent with previous findings (Melikian et al., 1996), biotinylated fractions were highly enriched for the $80 \mathrm{kDa}$ form of the protein (Fig. 2A,B). hNET-A457P surface expression was significantly diminished to $34.4 \pm 4.5 \%$ of hNET-wt $(p<0.001 ; n=4)$ (Fig. $2 \mathrm{~B})$. Notably, the immature form of hNET-A457P reaches the surface at levels equivalent to immature hNET-wt. The $54 \mathrm{kDa}$ form of hNET-wt in transfected cells represents an early stage in $\mathrm{N}$-glycolytic processing. We sought to establish that the $54 \mathrm{kDa}$ form of hNET-A457P represents an immature transporter rather than a comigrating, partially degraded form derived from the 80 $\mathrm{kDa}$ form. We therefore evaluated the EndoH sensitivity of mutant transporters and found that, like hNET-wt, the hNETA457P $54 \mathrm{kDa}$ form is shifted after EndoH treatment to an apparent mass of $46 \mathrm{kDa}$ (Fig. 2C), like that of hNET-wt. In contrast, the $80 \mathrm{kDa}$ forms expressed by hNET or hNET-A457P, as expected, were insensitive to EndoH treatments.

The heterozygous nature of hNET-A457P in the OI family suggested to us a potential influence of the mutation on hNET-wt function that merited additional study. Dominant-negative interactions attributable to the presence of a mutant allele are well described for many genes and can arise from adverse interactions with the normal protein. We first sought functional evidence for dominant-negative interactions in transport assays using COS-7 cells cotransfected with hNET-wt and hNET-A457P. Cotransfection of hNET-A457P and hNET-wt decreased uptake to $60.9 \pm$ $4.0 \%$ of the levels achieved with transfection of hNET-wt alone $(p<0.05 ; n=4)$ (Fig. 3A). To determine the mechanism of this dominant-negative effect, differentially tagged constructs were used in biotinylation experiments. Previous observations in our laboratory (Bauman and Blakely, 2002; Sung et al., 2003) and the present experiments indicated that $\mathrm{N}$-terminal epitope tags on hNET do not appreciably influence the level of hNET protein expression or the ability of hNET to transport NE. Blots probed using an anti-HA antibody revealed a 50\% decrease in the surface expression of HA-hNET-wt when cotransfected with His-hNETA457P compared with HA-hNET-wt transfection alone (Fig. $3 \mathrm{~B})$. Note that transfection of $200 \mathrm{ng}$ of HA-hNET-wt resulted in an increase in both total and surface expression relative to $100 \mathrm{ng}$ of HA-hNET-wt levels (Fig. 3B,C, lanes 1, 3). This increase is evident also for His-hNETA457P immunoreactivity, ascertained with an antibody that only recognizes the His-tagged form (Fig. $3 B, C$, lanes 4,5$)$. These findings suggest that the cotransfection of $100 \mathrm{ng}$ of hNET-wt and $100 \mathrm{ng}$ of hNET-A457P has not simply saturated the machinery involved in translation, processing, or

$\leftarrow$

experiments. Optical density was measured for each band with Quantity One software as described in Materials and Methods. ${ }^{*} p<0.0 .001$; Student's $t$ test. $C$, EndoH removes N-linked oligosaccharides from the $54 \mathrm{kDa}$ form of hNET-wt and hNET-A457P (filled arrow) to reveal core protein of $\sim 44$ and $46 \mathrm{kDa}$ (open arrow). EndoH does not remove complex oligosaccharides from the $80 \mathrm{kDa}$ form. 

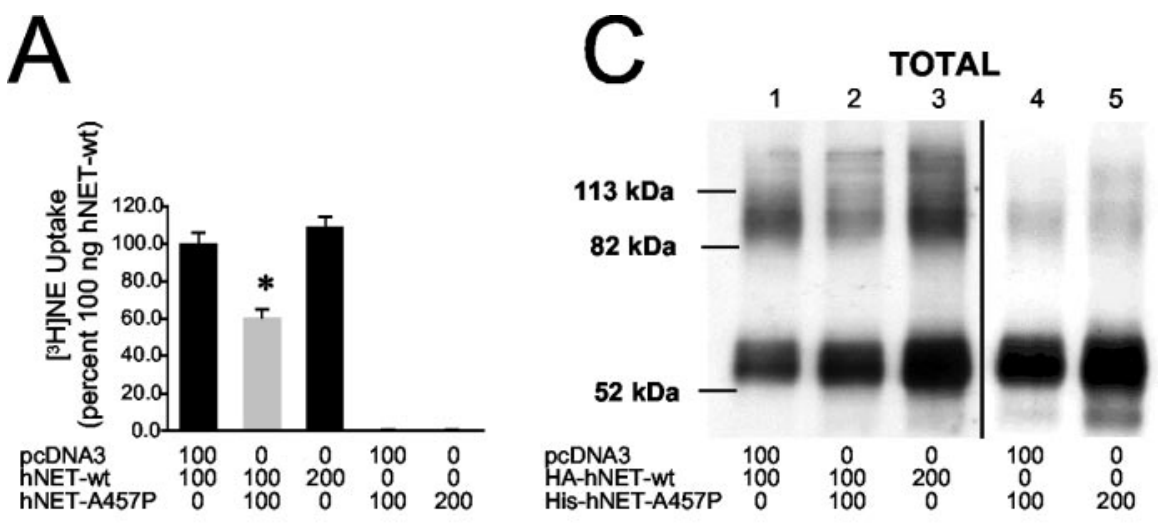

B
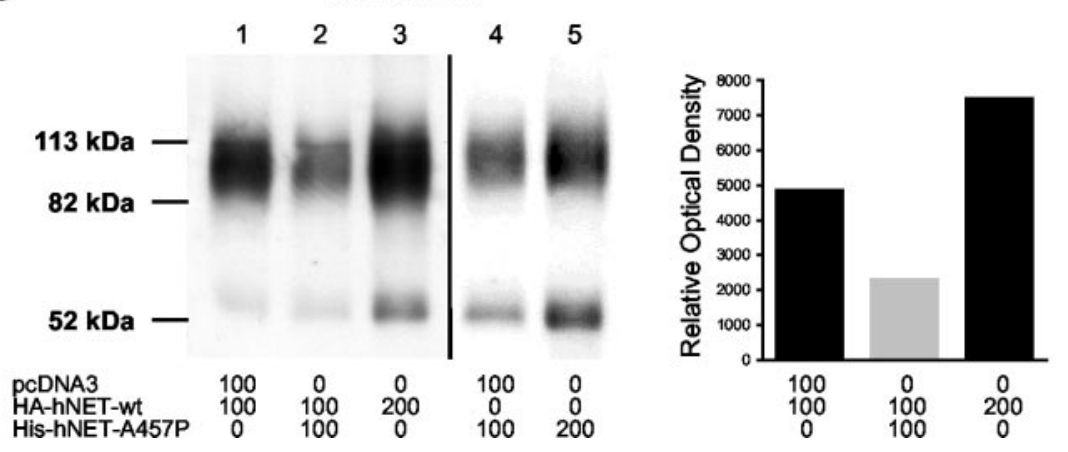

Figure 3. A, Dominant-negative effect of hNET-A457P on hNET-wt $\left[{ }^{3} \mathrm{H}\right] \mathrm{NE}$ transport in cotransfected COS-7 cells. COS-7 cells were transfected with hNET-wt and hNET-A457P or HA-hNET-wt and His-hNET-A457P. Amounts of DNA transfected are indicated under each lane (in nanograms). Twenty-four hours after transfection, $\left[{ }^{3} \mathrm{H}\right] \mathrm{NE}$ transport assays were performed as described in Materials and Methods. Data are the mean \pm SEM of four separate experiments. hNET-wt transport activity and the dominantnegative effect were equivalent using tagged or untagged hNETs, and results are combined. ${ }^{*} p<0.05$; Student's $t$ test. $B$, Dominant-negative effect of hNET-A457P on hNET-wt surface expression. COS-7 cells were transfected with HA-hNET-wt and His-hNET-A457P. Amounts of DNA transfected are indicated under each lane (in nanograms). Twenty-four hours later, cells were washed and subjected to biotinylation as described in Materials and Methods. Immunoblots were performed of biotinylated proteins using anti-HA-HRP to probe for HA-hNET-wt (lanes 1-3) and anti-NET to probe for His-hNET-A457P (lanes 4,5). The graph to the right shows quantitation of $80 \mathrm{kDa}$ bands in $B$ as described in Materials and Methods. C, Immunoblot of total lysates from experiments described in B using anti-HA-HRP to probe for HA-hNET-wt (lanes 1-3) and anti-NET to probe for His-hNET-A457P (lanes 4,5).

trafficking of transporters. Rather, these data suggest that hNETA457P, through its own aberrant trafficking, influences the trafficking of hNET-wt to the plasma membrane. Furthermore, cotransfection of His-hNET-wt and HA-hNET-wt did not result in the dominant-negative effect on HA-hNET-wt surface expression produced by His-hNET-A457P (Fig. 4A). Additionally, surface levels of hNET-A457P were not altered when cotransfected with hNET-wt, indicating that surface protein did not indiscriminately decrease as a result of cotransfection and that hNET-wt is not capable of rescuing hNET-A457P delivery to the plasma membrane (Fig. $4 B$ ). To further demonstrate a selectivity of the effect of hNET-A457P on hNET-wt, we examined the influence of hNET-A457P on the surface expression of the $\alpha 2 \mathrm{a}$ adrenergic receptor. Cotransfection of either hNET-A457P or hNET-wt with the $\alpha 2 \mathrm{a}$ adrenergic receptor construct HA-tag $\alpha 2 \mathrm{aAR}$ did not affect the surface expression of the receptor (Fig. $4 C$ ).

Evidence of dominant-negative interactions between hNETA457P and hNET-wt suggests the possibility of nonproductive oligomeric associations. We sought to provide direct evidence for this through coimmunprecipitation of differentially tagged hNET proteins. Because coimmunoprecipitation of hNETs has not been demonstrated previously, we first cotransfected cells with His-tagged and HA-tagged constructs of hNET-wt. Anti-His immunoprecipitates were collected on protein-G Sepharose beads, eluted, and blotted using anti-HA, revealing coimmunoprecipitation of HAhNET-wt and His-hNET-wt proteins of the $54 \mathrm{kDa}$ form (Fig. 5A, lane 3). No HAhNET-wt signal was observed in immunoprecipitates when either His-hNET-wt or HA-hNET-wt was transfected alone (Fig. 5A, lanes 1, 2, respectively). Mixing cells transfected separately with HIShNET-wt and HA-hNET-wt did not result in coimmunoprecipitation, suggesting that interactions did not arise as a result of nonspecific aggregation (Fig. 5A, lane 5). Furthermore, we quantitated the immunoprecipation and coimmunoprecipitation of the $54 \mathrm{kDa}$ form by measuring the hNET protein in the total cell extract and then in the supernatant after depletion by the anti-His antibody. The anti-His antibody depletes $85 \%$ of the His-tagged hNET-wt from the cell extracts, and $40 \%$ of HA-hNET-wt is coimmunoprecipitated (data not shown). HAhNET-wt was not depleted from extracts when the His-tagged form is not coexpressed. Conspicuously, the $80 \mathrm{kDa}$ form of HA-hNET-wt was absent in coimmunoprecipitated samples. This was not attributable to a lack of immunoprecipitation of this form because reprobing blots with an anti-NET antibody revealed the presence of the $80 \mathrm{kDa}$ form (Fig. $4 A$, lane 4). Similar results were obtained when we performed coimmunoprecipitations from the biotinylated fraction (data not shown). Together, these data reveal the ability of hNET to enter into stable oligomeric complexes that could support biosynthetic alterations observed in wt and mutant coexpression studies. To confirm the ability of hNET-A457P to engage in multimer formation, we performed coimmunoprecipitation studies using coexpressed hNET-wt and mutant transporters. As observed with tagged hNET-wt, His-hNET-A457P and HAhNET-wt coimmunoprecipitated (Fig. 5B). Quantitation revealed that $\sim 85 \%$ of His-hNET-A 457 P was immunoprecipitated by antiHis, and $60 \%$ of HA-hNET-wt was coimmunoprecipiated. The pattern of coimmunoprecipitated species was equivalent to that revealed in coimmunoprecipitation studies of hNET-wt, demonstrating the coimmunoprecipitation of $54 \mathrm{kDa}$ form and not the 80 $\mathrm{kDa}$ form.

\section{Discussion}

Expression of hNET-A457P in COS-7 cells yielded transport activity at $1-2 \%$ of hNET-wt levels, consistent with our previous observations in several other cell lines (Shannon et al., 2000). We examined the ability of hNET-A457P to bind its substrate in light of the inability of the mutant to transport NE. For these studies, we used NE competition for binding of the cocaine analog $\left.{ }^{125}\right]$ RTI-55. The NE $K_{\mathrm{i}}$ values we obtained for hNET-wt are 

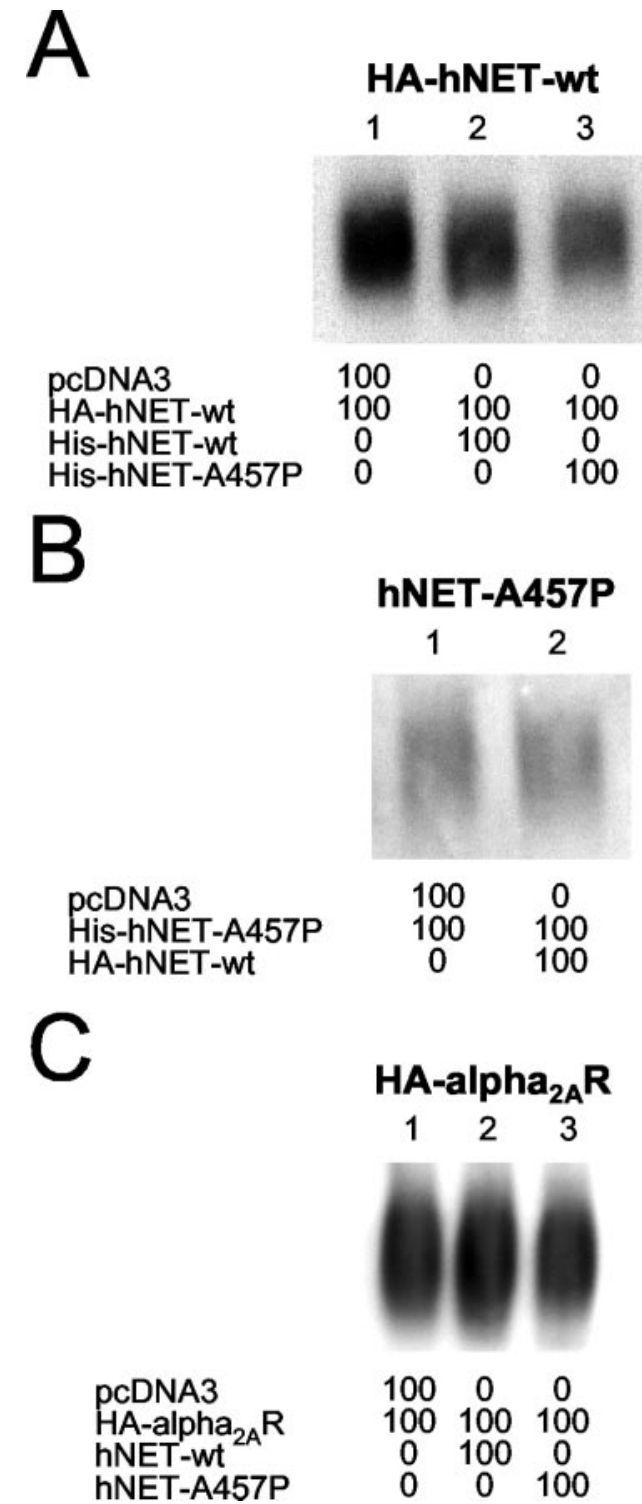

Figure 4. COS-7 cells were transfected with the indicated constructs and amounts of DNA (in nanograms). Twenty-four hours later, cells were washed and subjected to biotinylation as described in Materials and Methods. Immunoblot of biotinylated proteins were performed using anti-HA-HRP to probe for HA-hNET-wt $(A)$ and HA- $\alpha 2$ A receptor $(C)$ or anti-NET to probe for His-hNET-A457P (B).

similar to those reported in transfected cells and native tissues (Jayanthi et al., 1993; Gu et al., 1994; Eshleman et al., 1999). hNET-A457P demonstrated a fivefold increase in its $K_{\mathrm{i}}$ value for NE. A recent study (Paczkowski et al., 2002) reported that the hNET-A457P mutation expressed in COS-7 cells produces a more marked impact on NE inhibition of $\left[{ }^{3} \mathrm{H}\right]$ nisoxetine binding (16-fold) and on the NE transport $K_{\mathrm{m}}$ (53-fold). Consistent with these findings, we were able to detect NE transport activity (as much as $40 \%$ of wt) if we used very high $\left[{ }^{3} \mathrm{H}\right] \mathrm{NE}$ concentrations ( $500 \mu \mathrm{M}$; data not shown). We are cautious regarding these findings because the elevated concentrations diminish our signalto-noise ratio and introduce opportunities for nonspecific pathways to contribute to uptake. Regardless, we conclude similarly that a substantial impact on translocation efficiency occurs even at concentrations that we predict should saturate the NE binding site. We recognize that both studies use heterologous expression systems for ease of functional and biochemical analyses. The es-

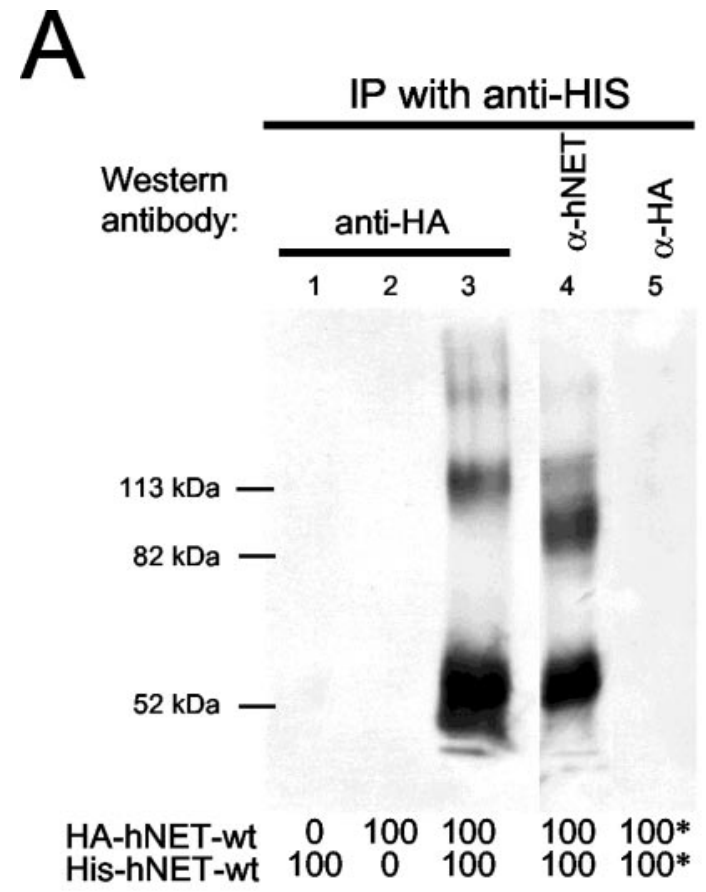

B

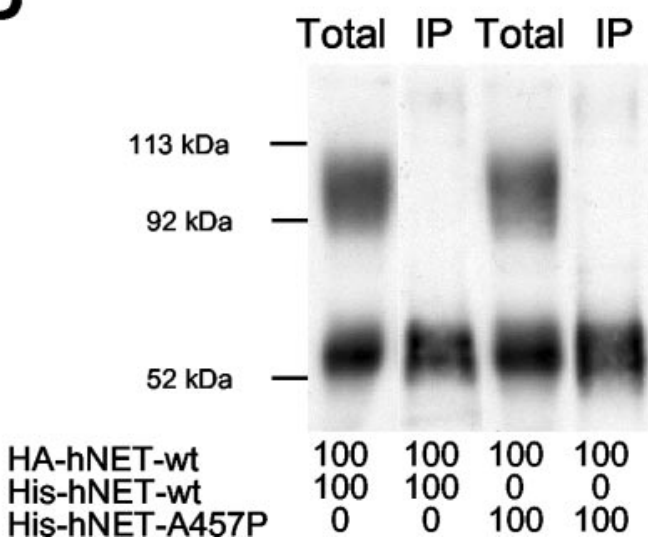

Figure 5. A, Coimmunoprecipitation of HA-hNET-wt with His-hNET-wt. COS-7 cells were transfected with His-hNET-wt and HA-hNET-wt. Amounts of DNA transfected are indicated under each lane (in nanograms). In one experiment (lane 5), cells were transfected separately with His-hNET-wt and HA-hNET-wt and mixed together after addition of extraction buffer $(*)$. Twenty-four hours after transfection, cell extracts were subjected to immunoprecipitation with anti-His, followed by immunoblot using anti-HA (lanes 1-3,5) or anti-NET (lane 4) antibody. B, Coimmunoprecipitation of HA-hNET-wt with His-hNET-A457P. COS-7 cells were cotransfected with either His-hNET-wt and HA-hNET-wt or with His-hNET-A457P and HA-hNET-wt. Twentyfour hours later, cell extracts were subjected to immunoprecipitation with anti-HIS, followed by SDS-PAGE of totals cell extracts and immunoprecipitates (IP). Immunoblot analysis was performed using anti-HA. This immunoblot is representative of equivalent results achieved with replication.

sential findings of this report were replicated in CAD cells, a catecholamine neuron-derived neuroblastoma (data not shown). We are also currently developing methods to evaluate NET protein in biopsies of OI subjects to address how well our predictions parallel in vivo circumstances.

Potential role of transmembrane domain 9 in hNET function A loss of catalytic function evident with surface-expressed hNETA457P protein may arise as a result of a global disruption of transporter structure or may indicate a contribution of trans- 
membrane domain (TMD) 9 to the transport process. Evidence suggests that TMD 9 may influence or participate in substrate binding and translocation. Chimeras generated from NET and dopamine transporter (DAT) that incorporate TMD 9 of NET generally retain substrate interaction and transport properties similar to that of NET (Giros et al., 1994; Buck and Amara, 1995). A chimera constructed of the serotonin transporter (SERT) with the NET extracellular loop 5, located between TMD 9 and TMD 10 and differing in only three amino acids between the two transporters, produced an almost complete loss of 5-HT transport and binding, whereas transporter surface expression was unaltered (Smicun et al., 1999). Amino acids located in the extracellular loop between TMD 9 and TMD 10 of hSERT influence transport-associated currents (Cao et al., 1998). Substitutions in the loops adjacent to TMD 9 in GAT1 modulate interaction with both ions and substrate (Golovanevsky and Kanner, 1999; Forlani et al., 2001). It is of course possible that the effects imparted through the mutation in TMD 9 arise as a result of proximity to other domains of the transporter, such as TMD 1 and TMD 3, that participate in substrate binding and translocation (Chen et al., 1997; Barker et al., 1999; Adkins et al., 2001). Clearly, additional work is needed to understand interhelical packing and whether the effect of hNET-A457P is imparted through proximal functional interactions or incorporates more distal regions of the transporter.

\section{Impaired glycosylation and surface expression of hNET}

The decrease in $B_{\max }$ of membrane RTI-55 binding to hNETA457P versus hNET-wt suggested a similar decrease in total protein expression of the mutant carrier. In addition, whole-cell $\left[{ }^{125} \mathrm{I}\right] \mathrm{RTI}-55$ binding revealed hNET-A457P binding sites to be $\sim 30 \%$ of hNET-wt levels, indicating a substantial loss of surface expression. Our radioligand binding results were additionally supported by immunoblots and biotinylation analyses that reveal a selective decrease in the amount of the $80 \mathrm{kDa}$ form of hNET known to be enriched at the cell surface. Previous work from our laboratory elucidated the biosynthetic progression of hNET protein in transfected cells, wherein a core $46 \mathrm{kDa}$ protein is rapidly glycosylated to a $54 \mathrm{kDa}$ protein and is further glycosylated to generate an $80 \mathrm{kDa}$ protein (Melikian et al., 1994). The present results in COS-7 cells reveal a pattern similar to that observed previously in other transiently transfected cell types (Melikian et al., 1996) whereby the $80 \mathrm{kDa}$ form is a minority of total protein but is highly enriched in surface fractions and only a small proportion of the $54 \mathrm{kDa}$ resides at the surface. The presence of the lower glycosylated form at the cell surface is likely contributed to by the high level of transporter expression generated by the amplification of protein expression inherent to COS-7 cells. The 80 $\mathrm{kDa}$ form of hNET-A457P was decreased to $\sim 35 \%$ of hNET-wt levels in total and biotinylated fractions. Possibly, mutant hNET could be processed normally but demonstrate sensitivity to proteolytic cleavage. However, we saw no evidence of accumulation of proteolyzed transporters. Moreover, the lower molecular weight species of hNET-A457P retains EndoH sensitivity, characteristic of immature transporters rather than partially degraded, mature carriers. Thus, we believe that the hNET-A457P mutation compromises a step in transporter biosynthetic progression between the endoplasmic reticulum (ER) and Golgi. Consistent with this idea, we observed no increase in the abundance of the $54 \mathrm{kDa}$ form at the cell surface, which presumably reaches the plasma membrane (at very low levels) without more complex glycolytic processing characteristic of the Golgi. The impact of hNET-A457P is thus qualitatively different from and more severe than that observed with mutation of hNET N-linked glycosylation sites, wherein the $46 \mathrm{kDa}$ core hNET protein reaches the plasma membrane efficiently and transports NE, although this carrier appears less stable at the surface (Melikian et al., 1996). Furthermore, because we detected no accumulation of the immature form of hNET-A457P, as has been observed for other hNET mutants (Bauman and Blakely, 2002), we suspect that the conformational perturbation introduced by the mutation targets the transporter for degradation during ER-Golgi transit. Mutation-induced trafficking defects, identified in clinical populations, can be rescued by stabilizing conformations with antagonists (so-called "chemical chaperones") or by reducing temperature to diminish effectiveness of ER-Golgi quality control machinery (Zhou et al., 1999; Morello et al., 2000). Our initial studies attempting to rescue surface expression have proven unsuccessful (M. K. Hahn and R. D. Blakely, unpublished observations) and the diminished transport capacity of the surface expressed mutant suggests limited utility of this approach.

There was a greater loss of hNET-A457P membrane binding compared with loss of total hNET-A457P protein measured by Western blot analyses, in which the deficit in protein was limited to the $80 \mathrm{kDa}$ form. One interpretation of these data are that the membrane binding data represent mainly surface forms, and we lost intracellular pools in our centrifugation step. This is not likely because, in the same membrane preparation from which binding is performed, Western blot analyses demonstrate both the 54 and $80 \mathrm{kDa}$ forms and in similar ratios to that observed in total cell extracts. However, to explore this possibility further, we subjected supernatants from membrane preparations to $200,000 \times g$ centrifugation to pellet any additional, lower-density material containing hNET binding sites. These experiments revealed that our initial lower-speed centrifugation did indeed recover $>90 \%$ of $\left[{ }^{125} \mathrm{I}\right] \mathrm{RTI}-55$ binding and hNET protein on Western blot analyses for both hNET-wt and hNET-A457P (data not shown). We therefore interpret these findings to indicate that hNET-A457P demonstrates a greater loss of RTI-55 binding compared with total protein levels and that $\sim 30 \%$ of hNETA457P protein binds RTI-55 with measurable affinity. It remains an open question at what stage in biosynthetic maturation through stages of glycosylation hNET-wt acquires a conformation capable of binding RTI-55 or other antagonists, but it is possible that RTI- 55 binding is acquired after glycosylation to the $80 \mathrm{kDa}$ form and thus membrane binding reflects this pool of transporters.

\section{hNET-A457P exerts a dominant-negative effect on hNET-wt} Our findings demonstrate a dominant-negative effect of a naturally occurring variant, hNET-A457P, on hNET-wt transporter function and surface expression. The specificity of this effect is supported by the lack of effect of a coexpressed differentially tagged hNET on itself or of hNET-A457P on coexpressed $\alpha 2 \mathrm{a}$ adrenergic receptor. The inability of hNET-wt to influence surface levels of hNET-A457P supports the dominant-negative nature of hNET-A457P and argues against a positive influence of hNET-wt to rescue the mutation. Transporter mutants and inactive splice variants have been reported to decrease surface expression and activity of wt transporters suggestive of homomultimeric interactions (Kitayama et al., 1999; Ramsey and DeFelice, 2002; Torres et al., 2002). Studies using biochemical and imaging techniques, electron microscopy, and concatenated constructs further support oligomeric structures of transporters (Chang et al., 1998; Eskandari et al., 2000; Kilic and Rudnick, 2000; Hastrup et al., 2001; Schmid et al., 2001). Recent evidence suggests that transmembrane domains of transporters may interact to support oligomer formation (Hastrup et al., 2001; Scholze et al., 2002; 
Torres et al., 2002). Our present studies add the first evidence of coimmunoprecipitation of tagged forms of hNET-wt and also demonstrate complexes containing hNET-wt and hNET-A457P. Several pieces of evidence support that the coimmunoprecipitation is indicative of oligomer formation and not attributable to a nonspecific aggregation of protein. First, we coimmunoprecipitated approximately one-half of HA-hNET with His-hNET, wt, or A457P, a substantial amount, at the same time consistent with an oligomer model in which a heteromultimer of the two different tagged forms will only be a fraction of the total multimers present. Second, coimmunoprecipation occurs with wt-wt hNET interactions, supporting that the process can occur in the absence of a mutant, misfolded protein. Third, the comimmunoprecipitated hNETs run as monomers on denaturing SDS-PAGE, suggesting that they are not trapped in aggregate form. Finally, coimmunoprecipitation of tagged hNETs only under conditions of coexpression but not after mixture of extracts from separately transfected cells supports that these interactions occur exclusively within the cell. Higher molecular weight bands were also observed in some experiments because a small percentage of total protein may represent aggregates, supported by their resistance to the denaturing SDS-PAGE conditions. Furthermore, this higher molecular weight form is routinely observed to a greater extent in hNET-A457P extracts, suggesting that misfolded protein does indeed contribute to this form of the protein.

We coimmunoprecipitated the $54 \mathrm{kDa}$ form of hNET, consistent with evidence that oligomers form in the ER before insertion in the plasma membrane (Margeta-Mitrovic et al., 2000; Scholze et al., 2002). The inability to recover the $80 \mathrm{kDa}$ form in coimmunoprecipitation experiments may reflect an instability of oligomers composed of complex glycosylated proteins under the extraction conditions used, such as has been observed for hDAT (Hastrup et al., 2001). Because we observed a dominant-negative effect on hNET-wt biosynthetic progression, we propose that hNET-A457P limits hNET-wt surface expression through the formation of nonproductive oligomers targeted to degradative pathways. This is consistent with recent evidence that hDAT mutants decrease wt surface expression via intracellular retention of the wt transporter (Torres et al., 2002). Our coimmunoprecipitation of the $54 \mathrm{kDa}$ form supports that interaction between monomers occurs before additional $\mathrm{N}$-glycosylation, and the incidence of hNET-wt/hNET-A457P oligomers suggests that quality control is initiated at the level of the complex. The high level of intracellular localization of NET in adrenal chromaffin cells and in axonal varicosities in brain (Schroeter et al., 1997) could foster an adverse influence of hNET-A457P on the pool of hNET-wt available for potential recruitment to the plasma membrane to meet demands for increased uptake.

The discovery of a heterozygous mutation in a monoamine transporter that is dominant negative has important implications for understanding the role of genetic variation in hNET in disease. The phenotype of family members carrying the mutant allele for hNET-A457P reinforces the concept that transport deficits generated by possessing a single effectual copy of hNET may be exacerbated by the presence of a dominant-negative mutant to result in altered NE homeostasis. Although we suspect that hNET-A457P is rare and may be limited to a single pedigree, there are likely other hNET polymorphic alleles with heterozygous expression in the population that could also act through a dominant-negative mechanism. The use of a cardiovascular endophenotype, such as the elevated heart rate described in the hNET-A457P pedigree, may aid in the identification of hNET genetic variability in other cardiovascular diseases and in psychiatric disorders.

\section{References}

Adkins EM, Barker EL, Blakely RD (2001) Interactions of tryptamine derivatives with serotonin transporter species variants implicate transmembrane domain I in substrate recognition. Mol Pharmacol 59:514-523.

Apparsundaram S, Galli A, DeFelice LJ, Hartzell HC, Blakely RD (1998a) Acute regulation of norepinephrine transport. I. protein kinase C-linked muscarinic receptors influence transport capacity and transporter density in SK-N-SH cells. J Pharmacol Exp Ther 287:733-743.

Apparsundaram S, Schroeter S, Giovanetti E, Blakely RD (1998b) Acute regulation of norepinephrine transport. II. PKC-modulated surface expression of human norepinephrine transporter proteins. J Pharmacol Exp Ther 287:744-751.

Backs J, Haunstetter A, Gerber SH, Metz J, Borst MM, Strasser RH, Kubler W, Haass M (2001) The neuronal norepinephrine transporter in experimental heart failure: evidence for a posttranscriptional downregulation. J Mol Cell Cardiol 33:461-472.

Barker EL, Moore KR, Rakhshan F, Blakely RD (1999) Transmembrane domain I contributes to the permeation pathway for serotonin and ions in the serotonin transporter. J Neurosci 19:4705-4717.

Bauman PA, Blakely RD (2002) Determinants within the C-terminus of the human norepinephrine transporter dictate transporter trafficking, stability, and activity. Arch Biochem Biophys 404:80-91.

Blakely RD (2001) Physiological genomics of antidepressant targets: keeping the periphery in mind. J Neurosci 21:8319-8323.

Bohm M, La Rosee K, Schwinger RH, Erdmann E (1995) Evidence for reduction of norepinephrine uptake sites in the failing human heart. J Am Coll Cardiol 25:146-153.

Bohm M, Castellano M, Flesch M, Maack C, Moll M, Paul M, Schiffer F, Zolk O (1998) Chamber-specific alterations of norepinephrine uptake sites in cardiac hypertrophy. Hypertension 32:831-837.

Brüss M, Kunz J, Lingen B, Bönisch H (1993) Chromosomal mapping of the human gene for the tricyclic antidepressant-sensitive noradrenaline transporter. Hum Genet 91:278-280.

Buck KJ, Amara SG (1995) Structural domains of catecholamine transporter chimeras involved in selective inhibition by antidepressants and psychomotor stimulants. Mol Pharmacol 48:1030-1037.

Cao Y, Li M, Mager S, Lester HA (1998) Amino acid residues that control $\mathrm{pH}$ modulation of transport-associated current in mammalian serotonin transporters. J Neurosci 18:7739-7749.

Chang AS, Starnes DM, Chang SM (1998) Possible existence of quaternary structure in the high-affinity serotonin transport complex. Biochem Biophys Res Commun 249:416-421.

Chen JG, Sachpatzidis A, Rudnick G (1997) The third transmembrane domain of the serotonin transporter contains residues associated with substrate and cocaine binding. J Biol Chem 272:28321-28327.

Eshleman AJ, Carmolli M, Cumbay M, Martens CR, Neve KA, Janowsky A (1999) Characteristics of drug interactions with recombinant biogenic amine transporters expressed in the same cell type. J Pharmacol Exp Ther 289:877-885.

Eskandari S, Kreman M, Kavanaugh MP, Wright EM, Zampighi GA (2000) Pentameric assembly of a neuronal glutamate transporter. Proc Natl Acad Sci USA 97:8641-8646.

Esler M, Jackman G, Bobik A, Leonard P, Kelleher D, Skews H, Jennings G, Korner P (1981) Norepinephrine kinetics in essential hypertension. Defective neuronal uptake of norepinephrine in some patients. Hypertension 3:149-156.

Foote SL, Bloom FE, Aston-Jones G (1983) Nucleus locus coeruleus: new evidence of anatomical and physiological specificity. Physiol Rev 63:845-914.

Forlani G, Bossi E, Ghirardelli R, Giovannardi S, Binda F, Bonadiman L, Ielmini L, Peres A (2001) Mutation K448E in the external loop 5 of rat GABA transporter rGAT1 induces $\mathrm{pH}$ sensitivity and alters substrate interactions. J Physiol (Lond) 536:479-494.

Galli A, DeFelice LJ, Duke BJ, Moore KR, Blakely RD (1995) Sodiumdependent norepinephrine-induced currents in norepinephrinetransporter-transfected HEK-293 cells blocked by cocaine and antidepressants. J Exp Biol 198:2197-2212.

Giros B, Wang YM, Suter S, McLeskey SB, Pifl C, Caron MG (1994) Delineation of discrete domains for substrate, cocaine, and tricyclic antidepres- 
sant interactions using chimeric dopamine-norepinephrine transporters. J Biol Chem 269:15985-15988.

Golovanevsky V, Kanner BI (1999) The reactivity of the gammaaminobutyric acid transporter GAT-1 toward sulfhydryl reagents is conformationally sensitive. Identification of a major target residue. J Biol Chem 274:23020-23026.

Gu H, Wall SC, Rudnick G (1994) Stable expression of biogenic amine transporters reveals differences in inhibitor sensitivity, kinetics, and ion dependence. J Biol Chem 269:7124-7130.

Hahn MK, Blakely RD (2002a) Gene organization and polymorphisms of monoamine transporters. relationship to psychiatric and other complex diseases. In: Neurotransmitter transporters. Structure, function, and regulation (Reith MEA, ed), pp 111-169. Totowa, NJ: Humana.

Hahn MK, Blakely RD (2002b) Monoamine transporter gene structure and polymorphisms in relation to psychiatric and other complex disorders. Pharmacogenomics J 2:217-235.

Hastrup H, Karlin A, Javitch JA (2001) Symmetrical dimer of the human dopamine transporter revealed by cross-linking Cys-306 at the extracellular end of the sixth transmembrane segment. Proc Natl Acad Sci USA 98:10055-10060.

Iversen LL (1961) The uptake of noradrenaline by the isolated rat heart. Br J Pharmacol 21:523-537.

Jacob G, Shannon JR, Costa F, Furlan R, Biaggioni I, Mosqueda-Garcia R, Robertson RM, Robertson D (1999) Abnormal norepinephrine clearance and adrenergic receptor sensitivity in idiopathic orthostatic intolerance. Circulation 99:1706-1712.

Jayanthi LD, Prasad PD, Ramamoorthy S, Mahesh VB, Leibach FH, Ganapathy V (1993) Sodium- and chloride-dependent, cocaine-sensitive, highaffinity binding of nisoxetine to the human placental norepinephrine transporter. Biochemistry 32:12178-12185.

Kilic F, Rudnick G (2000) Oligomerization of serotonin transporter and its functional consequences. Proc Natl Acad Sci USA 2000 97:3106-3111.

Kitayama S, Ikeda T, Mitsuhata C, Sato T, Morita K, Dohi T (1999) Dominant negative isoform of rat norepinephrine transporter produced by alternative RNA splicing. J Biol Chem 274:10731-10736.

Laemmli UK (1970) Cleavage of structural proteins during the assembly of the head of bacteriophage T4. Nature 227:680-685.

Leonard BE (1997) The role of noradrenaline in depression: a review. J Psychopharmacol 11:S39-S47.

Lorang D, Amara SG, Simerly RB (1994) Cell-type-specific expression of catecholamine transporters in the rat brain. J Neurosci 14:4903-4914.

Margeta-Mitrovic M, Jan YN, Jan LY (2000) A trafficking checkpoint controls GABA(B) receptor heterodimerization. Neuron 27:97-106.

Melikian HE, McDonald JK, Gu H, Rudnick G, Moore KR, Blakely RD (1994) Human norepinephrine transporter. Biosynthetic studies using a site-directed polyclonal antibody. J Biol Chem 269:12290-12297.

Melikian HE, Ramamoorthy S, Tate CG, Blakely RD (1996) Inability to $\mathrm{N}$-glycosylate the human norepinephrine transporter reduces protein stability, surface trafficking, and transport activity but not ligand recognition. Mol Pharmacol 50:266-276.

Merlet P, Dubois-Rande JL, Adnot S, Bourguignon MH, Benvenuti C, Loisance D, Valette H, Castaigne A, Syrota A (1992) Myocardial betaadrenergic desensitization and neuronal norepinephrine uptake function in idiopathic dilated cardiomyopathy. J Cardiovasc Pharmacol 19:10-16.

Mitchell K, Oke AF, Adams RN (1994) In vivo dynamics of norepinephrine release-reuptake in multiple terminal field regions of rat brain. J Neurochem 63:917-926.

Morello JP, Salahpour A, Laperriere A, Bernier V, Arthus MF, Lonergan M, Petaja-Repo U, Angers S, Morin D, Bichet DG, Bouvier M (2000) Pharmacological chaperones rescue cell-surface expression and function of misfolded V2 vasopressin receptor mutants. J Clin Invest 105:887-895.

Nelson $\mathrm{N}$ (1998) The family of $\mathrm{Na}^{+} / \mathrm{Cl}^{-}$neurotransmitter transporters. J Neurochem 71:1785-1803.

Pacholczyk T, Blakely RD, Amara SG (1991) Expression cloning of a cocaine- and antidepressant-sensitive human noradrenaline transporter. Nature 350:350-354.

Paczkowski FA, Bonisch H, Bryan-Lluka LJ (2002) Pharmacological properties of the naturally occurring Ala457 Pro variant of the human norepinephrine transporter. Pharmacogenetics 12:165-173.
Ramsey IS, DeFelice LJ (2002) Serotonin transporter function and pharmacology are sensitive to expression level: evidence for an endogenous regulatory factor. J Biol Chem 277:14475-14482.

Ritz MC, Cone EJ, Kuhar MJ (1990) Cocaine inhibition of ligand binding at dopamine, norepinephrine and serotonin transporters: a structureactivity study. Life Sci 46:635-645.

Sacchetti G, Bernini M, Bianchetti A, Parini S, Invernizzi RW, Samanin R (1999) Studies on the acute and chronic effects of reboxetine on extracellular noradrenaline and other monoamines in the rat brain. Br J Pharmacol 128:1332-1338.

Schildkraut JJ (1965) The catecholamine hypothesis of affective disorders: a review of supporting evidence. Am J Psychiatry 122:509-522.

Schmid JA, Scholze P, Kudlacek O, Freissmuth M, Singer EA, Sitte HH (2001) Oligomerization of the human serotonin transporter and of the rat GABA transporter 1 visualized by fluorescence resonance energy transfer microscopy in living cells. J Biol Chem 276:3805-3810.

Schnell O, Muhr D, Weiss M, Dresel S, Haslbeck M, Standl E (1996) Reduced myocardial 123I-metaiodobenzylguanidine uptake in newly diagnosed IDDM patients. Diabetes 45:801-805.

Scholze P, Freissmuth M, Sitte HH (2002) Mutations within an intramembrane leucine heptad repeat disrupt oligomer formation of the rat GABA transporter 1. J Biol Chem 277:43682-43690.

Schomig A, Dart AM, Dietz R, Mayer E, Kubler W (1984) Release of endogenous catecholamines in the ischemic myocardium of the rat. Part A: Locally mediated release. Circ Res 55:689-701.

Schomig E, Fischer P, Schonfeld CL, Trendelenburg U (1989) The extent of neuronal re-uptake of $3 \mathrm{H}$-noradrenaline in isolated vasa deferentia and atria of the rat. Naunyn Schmiedebergs Arch Pharmacol 340:502-508.

Schomig A, Haass M, Richardt G (1991) Catecholamine release and arrhythmias in acute myocardial ischaemia. Eur Heart J 12:38-47.

Schroeter S, Levey AI, Blakely RD (1997) Polarized expression of the antidepressant-sensitive serotonin transporter in epinephrinesynthesizing chromaffin cells of the rat adrenal gland. Mol Cell Neurosci 9:170-184.

Schroeter S, Apparsundaram S, Wiley RG, Miner LH, Sesack SR, Blakely RD (2000) Immunolocalization of the cocaine- and antidepressant-sensitive 1-norepinephrine transporter. J Comp Neurol 420:211-232.

Shannon JR, Flattem NL, Jordan J, Jacob G, Black BK, Biaggioni I, Blakely RD, Robertson D (2000) Clues to the origin of orthostatic intolerance: a genetic defect in the cocaine- and antidepressant-sensitive norepinephrine transporter. New Eng J Med 342:541-549.

Smicun Y, Campbell SD, Chen MA, Gu H, Rudnick G (1999) The role of external loop regions in serotonin transport. loop scanning mutagenesis of the serotonin transporter external domain. J Biol Chem 274:36058-36064.

Sung U, Apparsundaram S, Galli A, Kahlig K, Savchenko V, Schroeter S, Quick MW, Blakely RD (2003) A regulated interaction of syntaxin 1A with the antidepressant-sensitive norepinephrine transporter establishes catecholamine clearance capacity. J Neurosci 23:1697-1709.

Tatsumi M, Groshan K, Blakely RD, Richelson E (1997) Pharmacological profile of antidepressants and related compounds at human monoamine transporters. Eur J Pharmacol 340:249-258.

Tejani-Butt SM (1992) [ $\left.{ }^{3} \mathrm{H}\right]$ nisoxetine: a radioligand for quantitation of norepinephrine uptake sites by autoradiography or by homogenate binding. J Pharmacol Exp Ther 260:427-436.

Torres GE, Carneiro A, Seamans K, Fiorentini C, Sweeney A, Yao WD, Caron MG (2002) Oligomerization and trafficking of the human dopamine transporter: mutational analysis identifies critical domains important for the functional expression of the transporter. J Biol Chem 278:2731-2739.

Wilkerson RD, Sanders PW (1978) The antiarrhythmic action of amitriptyline on arrhythmias associated with myocardial infarction in dogs. Eur J Pharmacol 51:193-198.

Xu F, Gainetdinov RR, Wetsel WC, Jones SR, Bohn LM, Miller GW, Wang YM, Caron MG (2000) Mice lacking the norepinephrine transporter are supersensitive to psychostimulants. Nat Neurosci 3:465-471.

Zhou Z, Gong Q, January CT (1999) Correction of defective protein trafficking of a mutant HERG potassium channel in human long QT syndrome. pharmacological and temperature effects. J Biol Chem 274:31123-31126. 